ЕКОНОМІКА ПРИРОДОКОРИСТУВАННЯ ТА ЕКОЛОГІЗАЦІЯ НАВКОЛИШНЬОГО СЕРЕДОВИЩА

УДК 332.37

JEL Classification: Q 150, R 520

DOI: 10.37332/2309-1533.2020.1-2.20

\author{
Дзядикевич Ю.В., \\ д-р техн. наук, професор, проф. кафедри \\ економіки біоресурсів і природокористування, \\ Любезна I.B., \\ канд. екон. наук, доцент, доц. кафедри \\ економіки біоресурсів і природокористування, \\ Тернопільський національний економічний університет
}

СКЛАДОВІ ПРОЦЕСУ ПОКРАЩЕННЯ ЗЕМЛЕУСТРОЮ В УКРАЇНІ Dziadykevych Yu.V., dr.sc.(techn.), professor, professor at the department of bioresources and environmental management, Liubezna I.V., cand.sc.(econ.), assoc. prof., associate professor at the department of bioresources and environmental management, Ternopil National Economic University

\title{
COMPONENTS OF THE PROCESS OF IMPROVEMENT OF LAND MANAGEMENT IN UKRAINE
}

Постановка проблеми. Успішна реалізація земельної реформи залежить від багатьох чинників, зокрема: теоретичного обґрунтування та розвитку вітчизняного землеустрою, слабкої інституціональної підготовки реформи та підходів до ії̈ здійснення і відсутності чіткої правової бази. Досвід розвинених країн світу свідчить про те, що реформи, пов'язані з приватною власністю на землю, є економічним важелем, який примушує ефективно працювати господарські механізми у всіх сорерах економіки країни. Докорінні зміни у земельних відносинах, які очікуються в Україні, вимагають науково обґрунтованого поняття сучасного землеустрою та напрямів його покращення, оскільки система землеустрою є складною та трудомісткою. Вона охоплює організаційні структури, фрінансові механізми, низку нормативно-правових актів, формує дані для кадастрів і систем реєстрації прав на земельні ділянки, земельні інформаційні системи та механізми управління землекористуванням. Виробники сільського господарства повинні поставляти на ринок екологічно чисту продукцію, яка відповідає вимогам європейського ринку, а це вимагає ефективного землекористування. Землекористування передбачає збалансування економічних, екологічних і соціальних чинників із у рахуванням властивостей земельних ресурсів. Сталий розвиток землеустрою забезпечує захист довкілля, відновлення біосфери зменшення навантаження на природу та гармонійний розвиток людини і природи [1].

Аналіз останніх досліджень і публікацій. Розвитку землекористування в Україні присвячена низка робіт, зокрема: Є. Скорохода [2], А. Тихонова [3], Ю. Дзядикевича [4], С. Ганначенка [5], О. Бугайчука [6].

$€$. Скороход зазначає, що «сутність землекористування на засадах сталого розвитку полягає у збалансуванні економічних, екологічних і соціальних цілей із урахуванням властивостей земельних ресурсів» [2]. 
А. Г. Тихонов, Н.В.Гребенюк, О. В. Тихоненко, В. П. Феденко відмічають, що «земельні ресурси - це складова частина екосистеми, що є єдиним природним комплексом, який утворений живими організмами і середовищем» [3].

Ефективне використання земельно-ресурсного потенціалу України $€$ надзвичайно актуальною проблемою, оскільки недотримання екологічних параметрів розвитку аграрного виробництва в країні приводить до зменшення економічної ефективності використання сільськогосподарських угідь [4].

Погоджуємось із думкою про те, що «інноваційна ресурсозберігаюча технологія охоплює: точне землеробство, органічне землеробство, нульову та мінімальну технології. Технологія точного землеробства забезпечує одержання із земельної ділянки найбільшої кількості дешевої та якісної продукції, не порушуючи при цьому норм екологічної безпеки. Така технологія гарантує економію трудових ресурсів, енергетичних, управлінських і матеріальних витрат, а також підвищує врожайність сільгоспкультур і ефрективність виробництва» [5].

О. Бугайчук, досліджуючи сільськогосподарське землеволодіння в Україні, прийшов до висновку, що «побудова ефективного та раціонального землеволодіння в Україні є складним і довготривалим процесом, який буде мати відображення на всіх верствах населення» [6].

Однак, у літературних джерелах недостатньо висвітлені чинники, що впливають на процес покращення землеустрою в Україні, що зумовило необхідність їх подальшого вивчення. Україні.

Постановка завдання. Метою статті $€$ аналіз складових процесу покращення землеустрою в

Виклад основного матеріалу дослідження. Сутність землекористування на засадах сталого розвитку полягає у збалансуванні економічних, екологічних і соціальних чинників, враховуючи при цьому властивості земельних ресурсів. У Великому тлумачному словнику сучасної української мови зазначено, що «землеустрій - це сукупність заходів щодо організації землі й користування нею» [7, c. 363]. Землеустрій законодавчо визнано основоположним механізмом управління сфрерою використання й охорони земель. Сталий розвиток землеустрою забезпечує збереження довкілля, відновлення біосфери, зменшення навантаження на природу та гармонійний розвиток людини і природи. У Законі України «Про Землеустрій» зазначено, що «землеустрій - це сукупність соціальноекономічних та екологічних заходів, спрямованих на регулювання земельних відносин та раціональну організацію території адміністративно-територіальних одиниць, об'єктів господарювання, що здійснюються під впливом соціально-виробничих відносин і розвитку продуктивних сил» [8]. Землеустрій забезпечує впровадження державної політики у сферу використання та охорону земель, реалізацію земельної реформи та вдосконалення земельних відносин; наукове обґрунтування розподілу земель за цільовим призначенням, враховуючи при цьому державні інтереси, громадські та приватні, а також сприяє формуванню раціональної системи землеволодіння та землекористування. Землеустрій країни ґрунтується на таких основних принципах, а саме:

- дотримання законності та забезпечення науково обґрунтованого розподілу земельних ресурсів між галузями економіки;

- узгодження економічних, екологічних і соціальних інтересів суспільства, що забезпечують ефрективність виробничих процесів, економічну збалансованість і стабільність довкілля;

- забезпечення вимог екологічної безпеки та охорони земельних ресурсів і відтворення родючості ґрунтів.

Під час переходу промисловості до ринкової економіки виникають три форми власності. Перша форма ґрунтується на приватній власності на землю і має локальний характер. Друга фрорма регіонально-територіальна, яка охоплює комунальну власність на землю. Третя - це суспільна форма земельних відносин і має національний характер.

У земельних відносинах особливе місце займає «проблема їхнього фрормування i регулювання» [9]. Механізм регулювання земельних відносин розглядається з позиції політикоекономічної, економічної, екологічної та правової. Такий підхід сприяє розділу впливу політики, економіки, екології та права на процес фрормування і розвиток земельних відносин. Першість при цьому належить економічним законам. Ми погоджуємося з думкою, що «впровадження земельної політики на регіональному та місцевому рівнях із регулювання земельних відносин, організації землеустрою, ведення земельного кадастру та охорони земель необхідно зосередити в органах місцевого самоврядування. Діяльність у сфері землеустрою має бути сконцентрована на землевпорядному забезпеченні процесів децентралізації влади, формуванні нової системи адміністративно-територіального поділу та реформуванні місцевого самоврядування» [10].

У високорозвинених країнах світу до процесу розвитку територій залучаються асоціації муніципалітетів, національні агентства розвитку, торговельно-промислові палати, технополіси та інші інституції. 3 цією метою створюються венчурні, гарантійні та благодійні фонди, місцеві агентства розвитку і комунальні фундації. У цьому процесі важливе місце займають досягнення науки та передових технологій. Однією із складових інституціонального середовища землекористування $\epsilon$ розбудова інфраструктури ринку землі, яка передбачає перерозподіл земельних ресурсів за функціональним призначенням і галузевими особливостями. Однією із складових інституціонального 
середовища землекористування є розширення інфраструктури ринку земель, яка має обслуговувати перерозподіл земельних ресурсів. Важливою також $\epsilon$ проблема ефективного функціонування інститутів інфраструктури, що перетворюються в суб'єкти земельних відносин. Необхідно імплементувати низку елементів ринкової інфраструктури, що дозволить залучити земельні ресурси в господарську діяльність. Приймаючи до уваги переваги органічного землеробства, то доцільно впровадити його в сільськогосподарське виробництво. Це дасть позитивний результат у тому випадку, якщо буде запроваджений механізм державного впливу на процеси одержання органічної продукції.

Для сталого розвитку системи землекористування територій громад необхідно в схемах землеустрою враховувати особливості територіального планування систем землекористувань, формування обмежень у використанні земель і екомережі в межах територій громад [11].

На сьогоднішній день на рівні місцевого самоврядування відсутні механізми та інструменти ефективного управління землекористуванням. Рівень управління земельними ресурсами повинен відповідати концепції сталого розвитку. Регулювання процесу управління земельними ресурсами місцевих територіальних громад охоплює систему еколого-економічних відносин, яка передбачає підвищення рівня комплексного контролю за використанням земельно-ресурсного потенціалу та природоохоронної діяльності [12]. На місцевому рівні розв'язується низка завдань земельних ресурсів, зокрема:

- вдосконалення нормативно-правових актів щодо землекористування;

- проведення еколого-економічних заходів із землекористування;

- проведення робіт із оцінки землі;

- сприяння процесу формування збалансованого землекористування;

- встановлення контролю за використанням природних ресурсів.

Для реалізації вище згаданих завдань необхідно описати процес розробки системи управління земельними ресурсами, охороною довкілля та забезпечення екологічної безпеки території. Оцінка системи землекористування свідчить про те, що важливим компонентом цього процесу є показники вартісної оцінки земельного ресурсного потенціалу, які впливають на організаційно-господарські аспекти процесу та на формування ефективної землеохоронної діяльності.

Формування еколого-економічного механізму структуризації процесу землекористування обумовлює необхідність вироблення та застосування критеріїв щодо інформаційного забезпечення використання земель територіальних громад. Головним завданням еколого-економічного механізму формування системи управління на місцевому рівні $€$ врахування інтересів усіх груп користувачів землі з метою збереження довкілля та оптимального розподілу земельних ресурсів [12]. Важливим аспектом сталого розвитку є планування землекористування. Процес планування повинен базуватися на принципах, які відображають планування сталого землекористування: справедливість, міждисциплінарний підхід, безперервність процедури та розв'язання проблем планування і комплексна соціально-економічна оцінка території.

Досвід розвинених країн Європи та США свідчить, що ефективність управління землекористуванням забезпечується інструментами ринкової інфраструктури, а саме: товарні біржі, брокерські, посередницькі та інші фірми. Сутність землекористування на засадах сталого розвитку полягає у збалансуванні економічних, екологічних і соціальних цілей із урахуванням властивостей земельних ресурсів.

Земля є одним із обмежуючих чинників розвитку аграрної економіки, а землеволодіння та землекористування $є$ основою системи аграрних відносин. Відносини щодо володіння, користування та розпорядження землею регулюються нормативно-правовими актами, в основі яких є принципи рівності права власності на землю громадян, юридичних осіб, територіальних громад і держави. За даними Державного комітету по земельних ресурсах, загальна площа земель сільськогосподарського призначення становить 41,6 млн га [13]. Відповідно до Земельного Кодексу, в Україні $€$ три фрорми землеволодіння: державна, приватна та комунальна [14]. При державному землеволодінні суб'єктом є: Верховна Рада України та автономної республіки Крим, обласні, районні, міські, селищні та сільські ради народних депутатів. Об'єктом є усі землі України за винятком земель, які передані у комунальну або приватну власність. Приватне землеволодіння передбачає, що суб'єктом є фізичні особи (громадяни), а об'єктом є землі для ведення селянського (фермерського) господарства, особистого підсобного господарства, садівництва та дачного будівництва. У комунальному землеволодінні суб'єктом виступають територіальні громади сіл, селищ, міст в особі їх представницьких органів. Об'єктом є землі в межах населених пунктів, за винятком земель приватної та державної власності.

Поняття землеволодіння як форму власності можна розглядати через призму економічних i юридичних засад. Економічні засади характеризують відносини економічної власності на землю в аграрному секторі, а юридичні - це відносини, що виражені у відповідних правах власності на земельний наділ. Землеволодіння - це одноосібні або групові відносини, що виникають на основі формальних і неформальних прав, хто і на яких умовах, на який термін, і для яких цілей має право доступу до землі [6]. 
Багато українських вчених розглядають проблему розвитку землеволодіння як доступ до землі великих аграрних господарств і агрохолдингів. У своїх працях вони малу увагу звертають на приватні домогосподарства та їх сім'ї, які заробляють на землі основну частку свого сукупного доходу. Доступ до землі, для цієї категорії суспільства, є важливим елементом розвитку, продовольчої незалежності, екологічно чистого землеробства, планування та ін. Побудова ефективного та раціонального землеволодіння в Україні є складним і довготривалим процесом, який буде мати відображення на всіх верствах населення. Впровадження в аграрному секторі України новітніх технологій зумовлено зниженням родючості земель, зростанням ерозійних процесів, розширення площ деградованих і забруднених земель. Землекористування в Україні на сьогоднішній день здійснюється з порушенням структури посівів і, як наслідок, спостерігається виснаження ґрунтів, розвиваються ерозійні процеси, погіршується якісний стан сільськогосподарських угідь. У сучасних умовах аграрії використовують інноваційні ресурсозберігаючі технології обробітку ґрунту, які сприяють підвищенню ефективності виробництва та вимог щодо відновлення довкілля. Досвід країн ЄС свідчить про те, що ефективним $€$ застосування технології зберігаючого землеробства. Вона передбачає покращення якості ґрунтів і відновлення їхньої структури та вмісту гумусу, запобігання виникненню ерозійних процесів, нормалізує водний і повітряний режими та поліпшує екологічне середовище.

Інноваційна ресурсозберігаюча технологія охоплює: точне землеробство, органічне землеробство, нульову та мінімальну технології. Технологія точного землеробства забезпечує одержання найбільшої кількості дешевої та якісної продукції, не порушуючи при цьому норм екологічної безпеки. Така технологія передбачає дозоване внесення насіння, добрив і води в ґрунт. У США точність проведення польових робіт контролюється за допомогою супутника. Технологія гарантує економію трудових ресурсів, енергетичних, управлінських і матеріальних витрат, а також підвищує врожайність сільгоспкультур і ефективність виробництва. Застосування у землеробстві інноваційних ресурсозберігаючих технологій зупиняє деградацію земель, відтворює родючість ґрунту, забезпечує охорону земель і раціональне їх використання та покращує екологічний стан довкілля. Водночас спостерігається підвищення економічної ефективності аграрного виробництва та врожайності сільськогосподарських культур. Новітні технології забезпечують конкурентоспроможність сільгосппродукції та стабільність її виробництва [5]. Потрібно зауважити, що зниження природної родючості ґрунтів негативно впливає на використання аграрного ресурсного потенціалу територіальних громад. При реалізації екологічно безпечного аграрного виробництва актуальною проблемою $є$ відновлення родючості ґрунтів. Необхідно зазначити, що використання земельноресурсного потенціалу не відповідає вимогам екологічного, безпечного землекористування. Спостерігається зниження екологічної стійкості агроландшафтів, інтенсивне розорювання угідь, необґрунтована структура посівних площ і недостатнє внесення органічних і мінеральних добрив. Зниження природної родючості ґрунтів негативно впливає на використання аграрного ресурсного потенціалу територіальних громад. Все це привело до дегуміфікації ґрунтового покриву. Високий рівень розораності сільськогосподарських угідь і недотримання ґрунтозахисних заходів приводить до прискорення ерозійних процесів ґрунтового покриву. В останні роки суттєво зменшилася природна та економічна родючість ґрунту. Аграрії України останніми роками не проводять вапнування сільськогосподарських угідь, внаслідок цього погіршуються агрохімічні, фрізико-хімічні та фрізичні властивості кислих ґрунтів, а це призводить до зменшення їхньої родючості. В результаті сільгоспвиробники одержують низький урожай і поганої якості.

Найперспективнішим методом суцільного агроекологічного моніторингу є дистанційний аерокосмічний метод. Дистанційні дослідження дають можливість одержати оперативну й об'єктивну інформацію про динаміку кількісних і якісних показників ґрунтів, рослинного покриву, лісових масивів на великих територіях [15]. Ефективне землекористування вимагає проведення комплексних екологоекономічних заходів до землі як ресурсу та головного засобу виробництва. Збереження ґрунтового покриву та підвищення його ефективності у сільськогосподарському виробництві $є$ важливим для стабілізації екологічної ситуації, забезпечення продовольчої безпеки населення та сталого розвитку сільських територіальних громад.

За останніх десять років у країнах ЄС значно зросла кількість економічно стабільних органічних підприємств, які в майбутньому будуть впливати на розвиток сільського господарства. Необхідно зазначити, що в країнах ЄС під органічним сільським господарством зайнято понад 7,5 млн га ріллі. Особливо зросли площі земельних ділянок в Іспанії, Англії, Греції та в інших європейських країнах. Водночас в Україні органічне сільське господарство в 2010 році займало площу 300 тис. га угідь. Значний вклад у розвиток органічного сільського господарства вносить Міжнародна федерація сільськогосподарського органічного руху (IFOAM). Вона об'єднує понад 750 організацій із 100 країн світу. Її основні завдання - це глобальний обмін, кооперація та всесторонній розвиток екологічних систем землеробства. Країни ЄС мають свої національні плани розвитку органічного сільського господарства. Підтримка виробників органічної продукції передбачає гранти для програм розвитку сільських районів і їх правовий захист. У зв'язку з відсутністю в Україні законодавчої і нормативноправової бази та ефективної державної підтримки гальмується розвиток органічного сільського 
господарства. Однак у країні зростає заінтересованість споживачів і виробників у збереженні екології довкілля. Все це сприяє розвитку органічного сільського господарства та виробництві екологічно чистої продукції.

Національна безпека країни вимагає розв'язання низки проблем, а саме: охорони земель, збереження та відтворення родючості ґрунтів і раціоналізації й екологізації аграрного землекористування. Для успішного землекористування необхідно економічно заохотити власників землі та землекористувачів до самостійного проведення заходів, які передбачають раціональне використання й охорону земель. Застосування економічних інструментів регулювання земельних відносин сприятиме фрінансовій відповідальності землекористувачів, самодостатності регіонів і наблизить вітчизняних аграріїв до збалансованого та високопродуктивного сільськогосподарського виробництва. Успішний його розвиток забезпечує функціонування різних галузей економіки країни, а особливо її продовольчу безпеку. Міцний зв'язок із життєзабезпеченням населення країни робить його ще більш важливим і потребує належної уваги з боку держави. В країнах $€ C$ сільське господарство має державну підтримку (більше 50\%). Водночас в Україні розмір державної підтримки не перевищує 4\%. Державна допомога повинна враховувати особливості сільського господарства, його вклад у розвиток національної економіки, механізм державного регулювання повинен мати системний і комплексний підхід. Аграрно-промисловий комплекс постійно вимагає значних інвестицій, оскільки $€$ складною біотехнологічною природною системою. Необхідно зазначити, що в зв'язку з специфічними особливостями аграрний сектор не може бути конкурентоспроможним в умовах ринкової економіки. Необхідність активної ролі держави у функціонуванні економічних процесів зумовлена потребою у вирівнюванні зовнішніх чинників, які впливають на галузь, і нездатністю ринкового механізму вирішувати державні завдання. Це вимагає окреслення напрямів удосконалення механізму державного регулювання, розвитку та стимулювання. Перший напрямок оптимізує й деталізує функції спеціалізованого органу управління. Другий - охоплює схему моделі його організаційної структури 3 виділенням підсистем, які сприяють прискореному розвитку ринкової інфраструктури та адаптації агропромислового комплексу до ринкових реалій. Третій напрямок передбачає розробку моделі регулювання процесів агропромислової інтеграції й кооперації.

Висновки 3 проведеного дослідження. Отже, однією із складових інституціонального середовища землекористування $€$ розбудова інфраструктури ринку землі, яка передбачає перерозподіл земельних ресурсів за функціональним призначенням і галузевими особливостями.

Таким чином, сучасний стан агропромислового комплексу вимагає запровадження якісно нових напрямів розвитку аграрного сектора, зокрема, необхідно створити аграрні сільськогосподарські підприємства неприватної форми власності, а також значно розширити оренду земель і надання державою прав на володіння землями сільськогосподарського призначення. Ці заходи допоможуть подолати депресивність, яка $є$ в організації форм власності щодо земель аграрного сектора України.

\section{Література}

1. Дзядикевич Ю. В., Любезна І. В. Деякі аспекти землеустрою в Україні. Інноваційна економіка. 2018. № 5-6. С. 57-64.

2. Скороход $€$.В. Еколого-економічні аспекти сільськогосподарського землекористування на засадах сталого розвитку. АгроІнКом. 2012. № 12. С. 85-88.

3. Тихонов А. Г., Гребенюк Н. В., Тихоненко О. В., Феденко В. П. Наукові засади сталого розвитку землекористування: індикація екологічного стану. Землекористування. 2003. № 3. С. 15-20.

4. Економіка довкілля і природних ресурсів : монографрія / Ю.В.Дзядикевич та ін. Тернопіль, 2016. 392 c.

5. Ганначенко С. Л. Інноваційні ресурсозберігаючі технології в землеробстві. Економіка АПК. 2012. № 1. С. 99-103.

34.

6. Бугайчук О. В. Сільськогосподарське землеволодіння в Україні. Агро/нКом. 2012. № 12. С. 32-

7. Великий тлумачний словник сучасної української мови / уклад. та голов. ред. В. Т. Бусел. Київ, Ірпінь : Перун, 2001. 1440 с.

8. Про землеустрій : Закон України від 22.05. 2003 p. № 858-IV. URL: https://zakon.rada.gov.ua/laws/show/858-15/print (дата звернення: 17.01.2020).

9. Мартин А. Г., Прядка Т. М. Історичні аспекти формування земельних відносин і землеустрою в Україні : монографрія. Київ: Центр учбової літератури, 2013. 194 с. C. 5-10.

10. Гадзало Я. М. Проблеми завершення земельної рефрорми. Вісник аграрної науки. 2015. № 8.

11. Купріянчик І. П., Мельник Д. М., Салюта В. А. Інституційний підхід до планування розвитку системи землекористувань територій територіальних громад. Інвестиції: практика та досвід. 2018. № 16. C. 25-30. 
12. Таратула Р. Б. Еколого-економічний механізм структуризації процесу землекористування на місцевому рівні. Інвестиції: практика та досвід. 2016. № 23. С. 46-49.

13. Державний комітет України із земельних ресурсів. URL : www.kmu.gov.ua/control/uk/publish/article?art (дата звернення: 17.01.2020).

14. Земельний кодекс України : Закон України від 25.10.2001 р. № 2768-III. URL : https://zakon.rada.gov.ua/laws/show/2768-14 (дата звернення: 17.01.2020).

15. Письменська О. А. Розвиток органічного сільського господарства в Європі. Економіка АПК. 2012. № 2. C. 141-144.

\section{References}

1. Dziadykevych, Yu.V. and Liubezna, I.V. (2018), "Some aspects of land management in Ukraine", Innovatsiina ekonomika, no. 5-6, pp. 57-64.

2. Skorokhod, Ye.V. (2012), "Ecological and economic aspects of agricultural land use on the principles of sustainable development", AhrolnKom, no. 12, pp. 85-88.

3. Tykhonov, A.H., Hrebeniuk, N.V., Tykhonenko, O.V. and Fedenko, V.P. (2003), "Scientific principles of sustainable development of land use: principles, indications, indicators", Zemlekorystuvannia, no. 3, pp. 15-20.

4. Dziadykevych, Yu.V. et al. (2016), Ekonomika dovkillia i pryrodnykh resursiv [The economics of the environment and natural resources], monograph, Ternopil, Ukraine, $392 \mathrm{p}$.

5. Hannachenko, S.L. (2012), "Innovative resource-saving technologies in agriculture", Ekonomika APK, no. 1, pp. 99-103.

6. Buhaichuk, O.V. (2012), "Agricultural land tenure in Ukraine”, AhrolnKom, no. 12, pp. $32-34$.

7. Busel, V.T. (Ed.), (2001), Velykyi tlumachnyi slovnyk suchasnoi ukrainskoi movy [A great explanatory dictionary of the modern Ukrainian language], Perun, Kyiv, Irpin, Ukraine, $1440 \mathrm{p}$.

8. The Verkhovna Rada of Ukraine (2003), The Law of Ukraine "On land management" dated 22.05.2003 no. 858-IV, available at: https://zakon.rada.gov.ua/laws/show/858-15/print (access date January 17, 2020).

9. Martyn, A.H. and Priadka, T.M. (2013), Istorychni aspekty formuvannia zemelnykh vidnosyn $i$ zemleustroiu $v$ Ukraini [Historical aspects of the formation of land relations and land management in Ukraine], monograph, Tsentr uchbovoi literatury, Kyiv, Ukraine, 194 p.

10. Hadzalo, Ya.M. (2015), "Problems completion of land reform", Visnyk ahrarnoi nauky, no. 8, pp. 510.

11. Kupriianchyk, I.P., Melnyk, D.M. and Saliuta, V.A. (2018), "Institutional approach for planning of the land use systems development for the territories of local communities", Investytsii: praktyka ta dosvid, no. 16, pp. 25-30.

12. Taratula, R.B. (2016), "Environmental and economic mechanisms of the land use structuring at the local level”, Investytsii: praktyka ta dosvid, no. 23, pp. 46-49.

13. "State Committee on Land Resources of Ukraine", available at: www.kmu.gov.ua/control/uk/publish/article?art (access date January 17, 2020).

14. The Verkhovna Rada of Ukraine (2001), The Law of Ukraine "The Land Code of Ukraine" dated 25.10.2001 no. 2768-III, available at: zakon.rada.gov.ua/laws/show/2768-14 (access date January 17, 2020).

15. Pysmenska, O.A. (2012), "The development of organic agriculture in Europe", Ekonomika APK, no. 2, pp. 141-144.

Стаття надійшла до редакції 03.02.2020 p. 